\title{
鼻アレルギー・肥厚性鼻炎に対するレーザー治療
}

\section{LASER application to allergic rhinitis}

and hypertrophic rhinitis

中之坊 学, 井上鐵三，田部暂也，小倉雅実

M. Nakanoboh, T. Inouye, T. Tanabe, M. Ogura

防衛医科大学校耳鼻咽喉科

The $\mathrm{CO}_{2}$ Laser has been used in the treatment of allergic rhinitis and hypertrophic rhinitis for the past several years,

As we know, the Laser enables a surgeon to perform the operation with minimum hemorrhage and minimized pain, during and after the procedure,

Additionaly many of these operations $c$ an be performed under local anesthesia instead of general anesthesia and on an out patient basis.

The Laser is applied to the mucous membranes of the inferior turbinates. Vaporization and cutting is easily done.

Post operative treatment is easy.

The advantages of Laser surgery over regular surgical techniques are supreme for intranasal operations when performed under local anesthesia. 


\section{1. はじめに}

近年、アレルギー性鼻炎や肥厚性鼻炎の外科的 治療のてとつとして、レーザーによる下甲介粘膜 の蒸散および切除が行なわれるようになってきて いる。乙の治療法の利点として, 従来の外科的療 法と比較して, 手術時の出血・疼痛が少なく患者 の苦痛むほしんどない，またてれにより外来で容 易に行え入院を必要としない。鼻内タンポンも 不要で, 術後の処置む必要としない, など多くの ものが挙げられる。

1986 年以来, 我々の行ったてのレーザ一手術は 100 例を越え，有効な成績をおさおているので, こてに報告する。

\section{2. 対 象}

対象は 1986 年 3 月から 1990 年 9 月の間に当 科を訪れた嚾治性鼻アレルギー患者および肥厚性 鵕炎患者の計103名である。性別・年龄別分布を 表 1 亿示す。特記すべきとととしては，15歳以下 の小児18名之妊娠 3 ケ月の妊婦 1 名を含んでいる ことである。

\begin{tabular}{crc} 
& \multicolumn{2}{c}{ 表 1} \\
& Cases & \\
& & \\
& Male & Female \\
\hline$\sim 10$ & 1 & 0 \\
$\sim 20$ & 26 & 20 \\
$\sim 30$ & 8 & 7 \\
$\sim 40$ & 9 & 7 \\
$\sim 50$ & 7 & 5 \\
$50 \sim$ & 8 & 5 \\
\hline total & 59 & 44
\end{tabular}

\section{3. 方法}

全例外来にてレーザー手術を施行した。麻酔は， キシロカイン・ボスミンの鲎内表面麻䐴に加え, $1 \%$ キシロカインを下甲介粘膜下に局注するこよ により得た。実際には写真 1 のように行う。

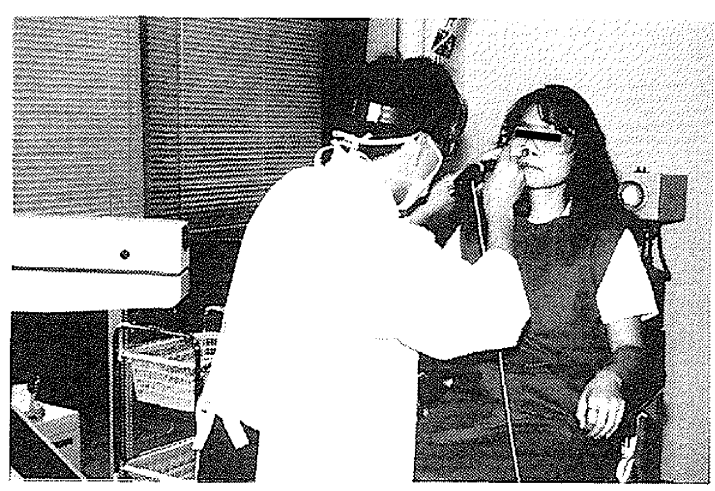

写真 1

用いるレーザーは， $\mathrm{CO}_{2}$ レーザーが主であるが， 1990 年 6 月以降, KT P / 532 レーザーを 用いる機会を得たので,てれについてむ言及する。 $\mathrm{CO}_{2}$ レーザーについては, XANAR社のXAM20 を用い,ハンドピースは写真 2 のような日本赤 外線工業社の古のを用いた。直射型ハンドピース で下甲介前端を処置したのちに，側射型ハンドピー スで甲介側面を十分に蒸散する。蒸散は defocused beam 15 Wで一側につき $5 \sim 10$ 分間行う。

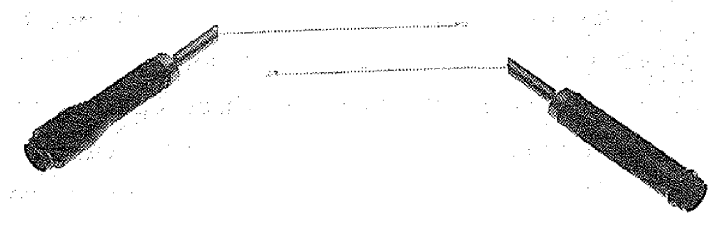

写真 2

$\mathrm{KTP} / 532$ レーザーは，止血能・切開能ともにバ

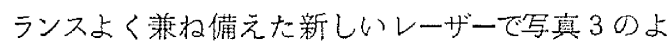
うなハンドピースの中に石英ファイバーのロッドを 通し下甲介粘膜に接触させながら，従来の剪刀に よる下甲介切除同椂の手技で行うことができる。 以上のレーザー手術に要する時間は約30分であ り，術後はタンポンの挿入を行なわず，そのまま 㷌宅させる。原則として, 止血剤。抗生剤・消炎 剤等の投与屯行なわない。

治療の効果判定は、床アレルギー日記により， 
急者の自覚症状（くしゃみ，舅汁，舅閉。および 舅症状全般）の変化を，消穴・著明改善，改善， 不変, 覀化の 5 段階に分けて検討した。

また無閉の改善度に関しては, RION 社製の舅 空通気度計 SR-11を用いて, 他覚的に検討した。

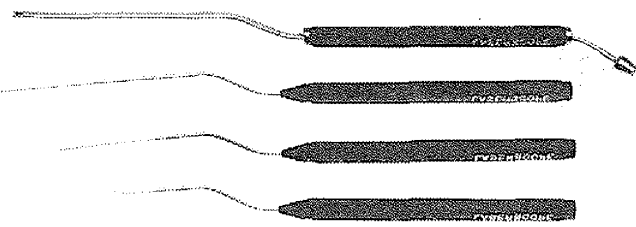

写真 3

\section{4. 結 果}

アレルギー日記による患者の自覚症状の変化を 図 1 に示した。改善以上を有効とすると。卑閉に 対しては $85 \%$ (1.03人中 88 人), 鼻汁代効しては63\% (82人中 52 人)。くしゃみに対しては $64 \%$ (56人中 36 人)に有効であった。鼾症状全般では79\%(103 人中 81 人)に有効であり，他外科的治潦法と同等以 上の効果が得られた。

術前術後に悬腔通気度を測定しえた症例のうち, 術前の與腔抵抗値が $0.3 \mathrm{pascal} / \mathrm{cm} / \mathrm{sec}$ 以上で,

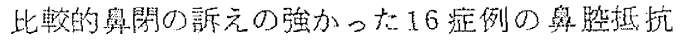
置の変化を図 2 亿示した。術前の抵抗值の平均 は $0.47 \mathrm{pascal} / \mathrm{cm} / \mathrm{sec}$ で古り，術後等のそれは,030 pascal $/ \mathrm{cm} / \mathrm{sec}$ あっった。抵抗傎の変化からあ十 分に與腔通気が改善さ扎ているとよがわかる。

\section{5. 考 察}

近年，悬アレルギーが耳䑁咽喉科領域で重きを 占めるに至って，種々の治潦法・治療蔡が開発さ れている。ての中で外科的治療法は，保存的治療 法が奏効しない難治例，特に浮嗹性変化が非可逆 的で強度の與閉を訴える者がその上い適沈よなっ ている。

現在行なわれている外科的治療法には，下甲介
Clinical. Response

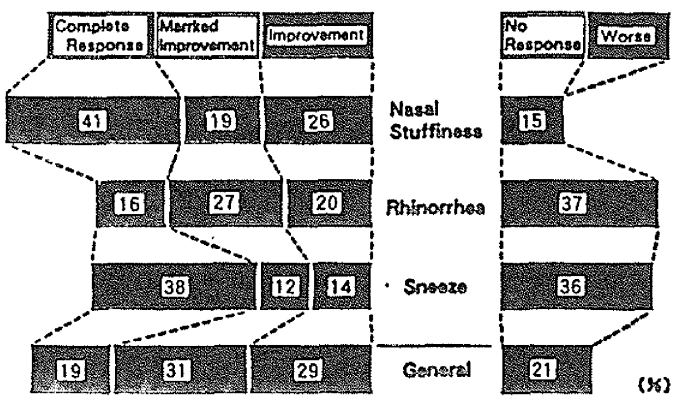

図 1

\section{Change of}

\section{Nasal Resistance \\ Nasal Resistance \\ (pascal $/ \mathrm{cm}^{3} / \mathrm{sec}$ )}

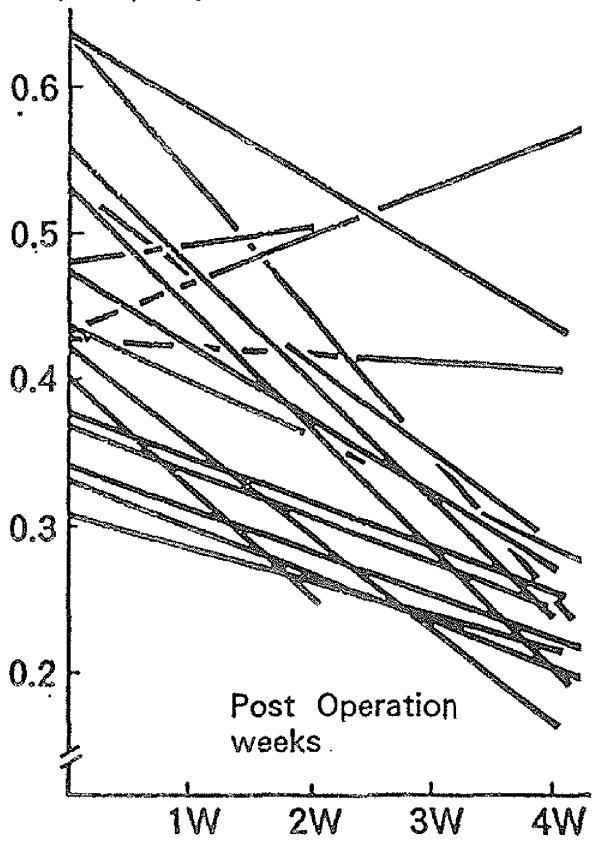

図 2

粘膜切除術, 電気、凝固法, グクイオサージャリー2! 下甲介化学刘手術 ${ }^{3}$ ），加えてレーザー手術などが ある。施設により異なった手技が用いられている ようであるが，治療成績に関しては，ほほ同等の 
結果が得られているようである。

我々は従来より $\mathrm{CO}_{2}$ レーザーを用い，番アレル ギーおよび肥厚性鼾炎化対する治療を行っており, その成績は前述の如く，他療法之同等あるいはそ れ以上の成績をおさめている。

レーザー手術の原理は，粘膜扔よび粘膜下層の 蒸散・切除により、腫脹した下甲介の減量をはか ると同時に, 同部を癜根組織に直換しアレルギー反 応の場を削減することにある。写真 4 上段は，治 療前のアレルギー虫者の下甲介粘膜の病理組織学 的所見で，間質の浮腫・好酸球の浸潤、鼻粘膜腺 の增大等典型的な厸アレルギーの像がみられてい る。中段は同症例のレーザー手術後 1 ケ月目の所 見であるが、間質が、毛細血管とコラーゲン線維 の增生を华う肉芽組織で置換されているのが見ら れる。上皮の修覆は未完成である。下段は，衡後 6 ケ月目の粘膜所見であるが，上皮は完全任再生 しており，間質の肉芽にはアレルギー反応の所見 はみられない。てれらの所見からもレーザー手術 の原理が理解される。

レーザー手術の回数については、熊沢ら年は週1 回の割で 5 回を 1 クールとして行なっているが, 我々は原則的には 1 回の手術のみで経過を観察す ることにしている。一度に可及的広範囲を蒸散・ 切除するてとにより鼎腔に十分なスペースが得ら れるように心がけている。

原理からも明らかなように，鼻閉に対しては, レーザー手術は十分なる効果を古げているものの， 泉汁・くしゃみに対しては、未だ十分に制衔され ているとはいえない。現時点では, 内服療法との 併用により满足できる結果芫得ている。

いずれにせよ、レーザーの最大の利点である出 血・疼痛が少ない上いうことを生かすととにより， 外来手術が可能亡なり, 術後タンポンむ処監李不 要之なった。患者の身体的, 精神的, さらには経 済的負担を大きく㯏減できたものと考える。

6. まटめ

1. 難治性鼠アレルギー患者と肥厚性䁷炎患者 に対しレーザー治潦を行い有効な結果を得た。

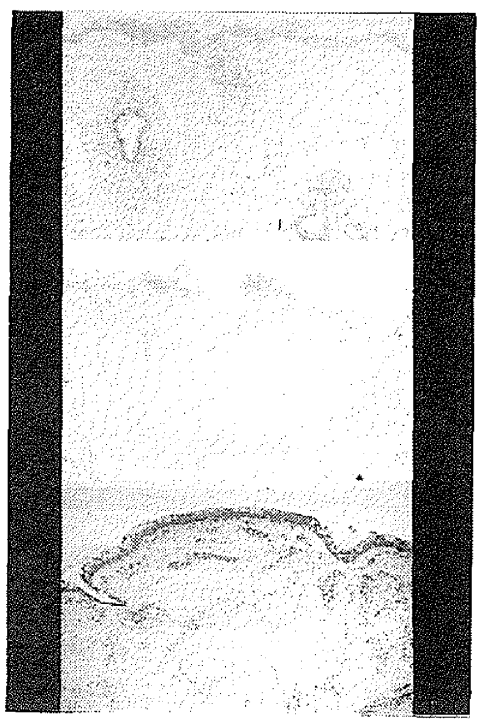

写貫 4

2. 本治療は, 出血・疼痛がほとんよ゙なく、術 後の処置む不要であるので外来で比較的容易に行 いうる。

3. 手術を行い難い小児・妊馐等に安安全に行 いうる。

参䓔文献

1）奥沢裕二 他；䁷甲介の電気凝固療法につい てー唽アレルギーを対象にして. 耳喉46:59 $\sim 63,1974$

2) 平出文久 他：アレルギー性鼻炎の凍結手術 による治療経験, 舅副鼻腔 19：157～158, 1980

3）八尾和雄 他: 下甲介化学剤手術, トリクロ 一ル酢酸の応用. 日耳翼 $91: 1031 \sim 1041$. 1988

4) 熊沢忠躬 他：レーザー手術, 耳喉頭頸 60: $537 \sim 540.1988$ 